\title{
Functionalism, Multiple Principals and the Reform of the NATO Secretariat after the Cold War
}

Citation for published version (APA):

Dijkstra, H. (2015). Functionalism, Multiple Principals and the Reform of the NATO Secretariat after the Cold War. Cooperation and Conflict, 50(1), 128-145. https://doi.org/10.1177/0010836714532919

Document status and date:

Published: 01/03/2015

DOI:

10.1177/0010836714532919

Document Version:

Accepted author manuscript (Peer reviewed / editorial board version)

\section{Please check the document version of this publication:}

- A submitted manuscript is the version of the article upon submission and before peer-review. There can be important differences between the submitted version and the official published version of record.

People interested in the research are advised to contact the author for the final version of the publication, or visit the DOI to the publisher's website.

- The final author version and the galley proof are versions of the publication after peer review.

- The final published version features the final layout of the paper including the volume, issue and page numbers.

Link to publication

\footnotetext{
General rights rights.

- You may freely distribute the URL identifying the publication in the public portal. please follow below link for the End User Agreement:

www.umlib.nl/taverne-license

Take down policy

If you believe that this document breaches copyright please contact us at:

repository@maastrichtuniversity.nl

providing details and we will investigate your claim.
}

Copyright and moral rights for the publications made accessible in the public portal are retained by the authors and/or other copyright owners and it is a condition of accessing publications that users recognise and abide by the legal requirements associated with these

- Users may download and print one copy of any publication from the public portal for the purpose of private study or research.

- You may not further distribute the material or use it for any profit-making activity or commercial gain

If the publication is distributed under the terms of Article $25 \mathrm{fa}$ of the Dutch Copyright Act, indicated by the "Taverne" license above, 


\title{
Functionalism, Multiple Principals and the Reform of the NATO Secretariat after the Cold War
}

\author{
2015 \\ Hylke Dijkstra \\ This is the electronic version of an article forthcoming in: \\ Cooperation and Conflict
}

\begin{abstract}
The literature on international organizations tells us that diverging member states preferences and concerns about the loss of control are major obstacles to institutional reform. But what if changes in the international environment necessitate institutional reform? This article examines such dilemma in the case of the North Atlantic Treaty Organization (NATO). NATO has faced functional pressures to adjust its machinery to the post-Cold War era, but has at the same time seen its membership and the preference heterogeneity of the membership increase. The article finds that institutional change
\end{abstract}


is indeed difficult with multiple principals and uncertainty about the consequences of reform. Yet modest reform has still taken place. First, strong functional pressures can help the member states to overcome their differences concerning institutional reform. Second, lower-level incremental reforms, beyond the control of the member states, have made NATO a more efficient organization. The empirical focus is on the development of the understudied International Staff post-1989.

\section{Keywords}

International organizations, institutional change, International Staff, NATO, security

\section{Introduction}

The North Atlantic Treaty Organization (NATO) is no longer the organization it used to be. For the first four decades of its existence, it was mostly concerned with the collective defence of Western Europe. This meant contingency planning for a Soviet attack, keeping up military capabilities and having internal dialogue between the allies. Since the end of the Cold War, its activities have expanded. NATO has also become active in the field of crisis management through military operations. It furthermore engages in partnerships with third states and international organizations in bringing about collective security. The new Strategic Concept (NATO 2010) indeed notes that NATO now has three core tasks: collective defence, crisis management and collective security. ${ }^{1}$

An important question is how substantive changes in international organizations affect the institutional machinery. Functionalist theory, for instance, expects institutions to follow substantive changes. As NATO carries out additional functions, there exists a clear rationale for institutional

1 This substantive transformation of NATO is well-documented in the academic literature (Yost 1998; Kaplan 2004; Asmus 2004; Rynning 2005, 2012; Webber, Sperling and Smith 2012; Herd and Kriendler 2013; Mayer 2014). 
reform (Wallander and Keohane 1999). We also know, however, that agreement among the member states constitutes a condition for change (e.g. Scharpf 1988; Pierson 2000; Tsebelis 2002; Nielson and Tierney 2003). And if anything, the membership and preference heterogeneity within NATO have increased since the end of the Cold War. NATO is thus an exciting case to explore the research question under which conditions do international organizations change their institutions.

The empirical focus of this article is on the NATO International Staff, which constitutes the permanent Brussels-based secretariat. ${ }^{2}$ The International Staff is headed by the Secretary-General and acts an agent of the member states in servicing the North Atlantic Council and its committees. It employs some 1250 officials and is at the heart of the machinery, yet constitutes only one part of the broader NATO system. ${ }^{3}$ Functionalist theory expects that the substantive changes in NATO have an impact on the International Staff. A redistribution of resources within the International Staff towards crisis management and collective security is likely. This may require changes in the organizational structure. Principals are, however, likely to object to such institutional changes. Some have a vested interest in collective defence and may resent the shift of resources. Others may fear the inevitable uncertainty that institutional reform brings in terms of future payoffs and control over NATO.

As the literature on multiple principals suggests, this article shows that substantive and institutional reform do not have to go hand-in-hand. The diverging preferences of the member states have been a major obstacle for institutional change. Even reform-minded member states, such as the United States, fear that they lose control over the International Staff as a result of the consequences of institutional reform. Modest reform has nonetheless taken place. First, functional pressures can help the member states to overcome their differences. Making the International Staff ready for the challenging operation in Afghanistan, for instance, has resulted in reform. Second, there has been an incremental reallocation of resources to improve NATO's functioning in crisis management and

2 The International Staff remains understudied. This is one of the first articles to trace its institutional development since the end of the Cold War.

3 NATO also has a military decision-making structure with a Military Committee and an International Military Staff. In addition, NATO has an extensive command structure and various agencies. Mayer (2014) sheds light on some of the other NATO institutions. Reform efforts (continue to) take place in the whole NATO machinery. 
collective security. This process has mostly been beyond the formal control of the member states. To conclude, preference heterogeneity cannot fully account for the institutional development of the NATO International Staff.

The starting point is the dilemma in the literature between functionalism and multiple principals in institutional reform. The article subsequently explores how the International Staff has focused increasingly on policy issues at the expense of support functions. It continues by tracing the three rounds of institutional reform. In the conclusion, the consequences for the scholarship on international organization are discussed.

\section{Functionalism, Multiple Principals and Institutional Reform}

Functionalist theory provides a useful baseline for a discussion on the reform of international organizations. It explains the existence of institutions in terms of their effects (Keohane 1984; also Pierson 2000). The NATO International Staff facilitates the work of the Alliance by chairing committees, writing reports and decisions, monitoring the implementation of decisions and acting as a contact point for third parties. The member states could carry out these functions themselves, but they have 'outsourced' them (Tallberg 2002: 25) in the interests of neutrality, expertise, continuity and efficiency. It is interesting to add a temporal dimension to this functionalist theory (cf. Pierson 2004). International organizations feel continuous pressure to adjust their functions and designs to environmental demands (Koremenos, Lipson and Snidal 2001; Dijkstra 2012). For the case of NATO, the functionalist story is thus the following: the environment has changed since the end of Cold War. NATO has expanded its functions to survive. This has affected its institutional design as well.

Institutional reform does, however, not always follow the functionalist road (e.g. Streeck and Thelen 2005). The literature on reform in international organizations deals, in particular, with the 
problématique of multiple principals and preference heterogeneity. Daniel Nielson and Michael Tierney (2003), for example, show that only after preference convergence of the member states, the World Bank started to make its lending policies more environmentally friendly. Fritz Scharpf (1988) comes to similar conclusions. He shows how policies such as the European Union's (EU) Common Agricultural Policy, which were once successful, became inefficient due to changing circumstances, yet were almost impossible to reform. George Tsebelis (2002) perhaps discusses these issues most elegantly in his work on veto players. He simply notes that "to change policies ... a certain number of ... actors have to agree to the proposed change" (p. 2).

Institutional reform is often regarded to be even more difficult to achieve than substantive reform (Pierson 2000: 490-491). By being able to change the rules of the game, it becomes possible to engage in substantive reform afterwards. Multiple principals may therefore agree on a substantive change now, but are unlikely to agree to institutional change if there is uncertainty about how it affects their future payoffs (Jupille, Mattli and Snidal 2013). This creates a status quo bias. To put it differently, institutional change might well be better for all member states involved, but if they are uncertain about it, they may still decide to stick with what they have.

The case of NATO is illustrative. The member states have been reasonably successful in achieving substantive reform, but much less so with regard to institutional reform. Substantive reform after the Cold War became inevitable for the survival of the alliance. To use the a popular phrase from a US senator, NATO had to go "out-of-area or out of business" (Lugar 1993). The United States had a credible alternative, namely unilateral action. If the other member states had not (partially) given in to the demands of the United States, such as out-of-area operations and global partnerships, it would have meant the end of NATO. This has not meant, however, that member states have been willing to risk their institutional control over NATO and the International Staff.

Since the control mechanisms of the member states are such a central feature in the design of international organizations, it is worth discussing how member states exert control over 
international secretariats. They use different mechanisms. First, member states control the resources of secretariats, such as budget and personnel. These resources are related to the ability of secretariats to affect policy outcomes (e.g. Biermann and Siebenhüner 2009; Oestreich 2012; Dijkstra 2013). Second, high-level posts may be strategically distributed among the member states (Kleine 2013), while lower positions may be subject to geographical balance. Third, contract policy also affects control with staff on permanent contracts having more autonomy than 'temporaries' or 'secondees' (Trondal 2006; Trondal, van den Berg and Suvarierol 2008). Finally, large member states may have privileged access allowing them to exert excessive informal influence (Stone 2011).

Faced with preference heterogeneity, is it possible to reform international organizations? While scholars have suggested several 'exit mechanisms' from inefficient substantive policies (see Falkner 2011), possibilities for escape from institutional lock-ins are more limited. ${ }^{4}$ They concern mainly consensus-promoting mechanisms (Scharpf 1988 and Falkner 2011). Initiators of change need to convince the multiple principals that outcomes of reform are better than the status quo. The negotiation process is thus important (Finke, König, Proksch and Tsebelis 2012). Scharpf (1988) concludes that only after a problem-solving rather than a confrontational style was adopted in EU and German negotiations, the principals were able to opt for reform. Such an approach seems important for NATO, where trust is critically important (Menon and Welsh 2011: 86). In realizing institutional reform, the involvement of an 'honest broker' makes sense (Abbott and Snidal 1998: 22-23; Beach 2005; Tallberg 2006). Leadership by secretariat staff in creating an atmosphere of trust, explaining the effects of the reforms, and exercising authority is thus important.

Secretariat officials can also try to circumvent the direct control of the member states, as control mechanisms are costly (e.g. Hawkins et al. 2006). Monitoring requires resources on the side of the principals, and the agent typically knows better how to run his/her own organization than the principals. It is therefore unrealistic to expect complete control. This gap naturally allows the NATO

4 Several exit mechanisms to achieve substantive reform are side-payments and issue-linkage, changes in applicable law and venues (e.g. Treaty reform), intervention by supranational actors including courts, mobilization of private actors (Falkner 2011). 
International Staff some autonomy when it comes to smaller changes (Thatcher and Stone Sweet 2002; Lake and McCubbins 2006: 343). ${ }^{5}$ For example, while the member states may dictate basic rules governing the recruitment of personnel, they may find it too costly to get involved in the selection procedure of individual applicants. Similarly, the allies may have ideas about the overall organization of their secretariat, including the number of divisions, but may want to leave the allocation of personnel within divisions to division heads. In other words, the high costs of control allow agents leeway over their organization.

Table 1. Drivers of institutional reform in international organizations

\begin{tabular}{|l|l|c|}
\hline H1 & Changing functions & + \\
\hline H2 & Multiple principals & - \\
\hline H3 & Secretariat leadership & + \\
\hline
\end{tabular}

The literature thus identifies different drivers and obstacles for reform. They have been summarized in three hypotheses in Table 1. The first hypothesis follows from functionalist theory and the expectation that a change in substantive functions will affect institutional design. The second one states that multiple principals, which have different preferences and are uncertain about the effects of reform, form an obstacle to institutional change. The final hypothesis notes that Secretariat leadership improves that chances of institutional change. These three hypotheses will be used to guide the empirical sections in the remainder of this article. They are mentioned where they help to explain instances of reform. The conclusion of this article further discusses the importance of these hypotheses and how they can be used to improve our understanding of institutional reform.

5 A competing hypothesis in the public administration literature is that bureaucrats themselves use their discretion to block institutional change (for classic statements on inertia and bureaucratic interests, see Merton 1940 and Downs 1967). In the case of NATO, officials have an interest in keeping their organization relevant. This has made many of them, as will be shown empirically, advocates of institutional reform. 


\section{More Tooth, Less Tail: The International Staff in Numbers}

This first empirical section presents an overview of developments in the NATO International Staff (1989-2011) with an emphasis on staff resources. It shows two things. First, the expansion of NATO's substantive functions has not led to an increase in overall resources. The member states have kept the civil budget flat. This has been an obstacle for change, as it meant that staff resources for NATO's new tasks had to come at the expense of its original function. Second, member states have had much less control over how the civil budget is spent within the International Staff. Since the end-1990s, the number of policy staff has incrementally increased, while support staff has been cut. Savings at the lower end of the hierarchy have thus been used to allow the International Staff to work on NATO's new tasks. This is points towards the limits of full control by the member states.

The starting point is overall budgetary policy. For most of the last two decades, France has insisted on zero budgetary growth, as it sees NATO in direct competition with the emerging security structures in the EU (preference heterogeneity, hypothesis \#2). ${ }^{6}$ Without additional funds, it has been difficult for the International Staff to increase numbers in spite of NATO's new core tasks. The International Staff has thus hardly grown since the end of the Cold War. It consisted of 1228 fulltime equivalent posts in 1989 and 1245.1 in $2011 .^{7}$ In fact, as a result of the economic crisis, NATO's budget now no longer follows inflation, which means that the International Staff has to cut 106 posts by 2015 (interview \#2, \#3 and \#5). Transforming an organization without additional resources is difficult, as it means that new tasks come at the expense of old tasks. Particularly the Central and Eastern European allies object. Contrary to expeditionary-minded member states (e.g. United States and United Kingdom), they continue to have an interest in collective defence, as they consider Russia still a threat. This is evidence of how the interests of multiple member states are an obstacle to institutional reform (hypothesis \#2).

6 Recently Germany and the United Kingdom have joined France albeit for different reasons (US Mission 2009; interview \#5).

7 All post-Cold War staff numbers have been provided by NATO officials. 
Yet despite such stringent constraints on staff resources, an incremental development within the International Staff has taken place since the end-1990s prioritizing policy substance over support functions. The timing of this development was not a coincidence. In 1999, NATO launched the military operation in Kosovo, thereby definitely establishing itself as one of the key actors in the field of crisis management. This resulted in a number of structural reforms to the International Staff under Secretary-General Lord Robertson (see furthermore below). Most of the 2000s were about preparing the challenging military operation in Afghanistan. Troop deployments reached record levels in 2010, when some 140,000 soldiers were serving under NATO command. The Afghanistan mission created considerable pressure for the International Staff to reform itself and prioritize policy substance.

There have been several important incremental changes. First of all, the balance within the International Staff has markedly changed. Since the late-1990s, the number of staff members in policy grades $(\mathrm{A}+\mathrm{U})$ has increased by $46 \%$ (148.1 posts), while the number of manual personnel $(\mathrm{C}$ grade) has decreased by almost 40\% (137 posts) (see figure 1). The decrease in manual personnel became possible through the better use of technology and more efficient working methods (interview \#11). Some of the security staff have also been outsourced (interview \#7 and \#11). These savings have not gone back to the member states, but have been used to expand the organization. This trend continues. For example, the current overall decrease in staff numbers will mostly impact on the support categories (interview \#5). 


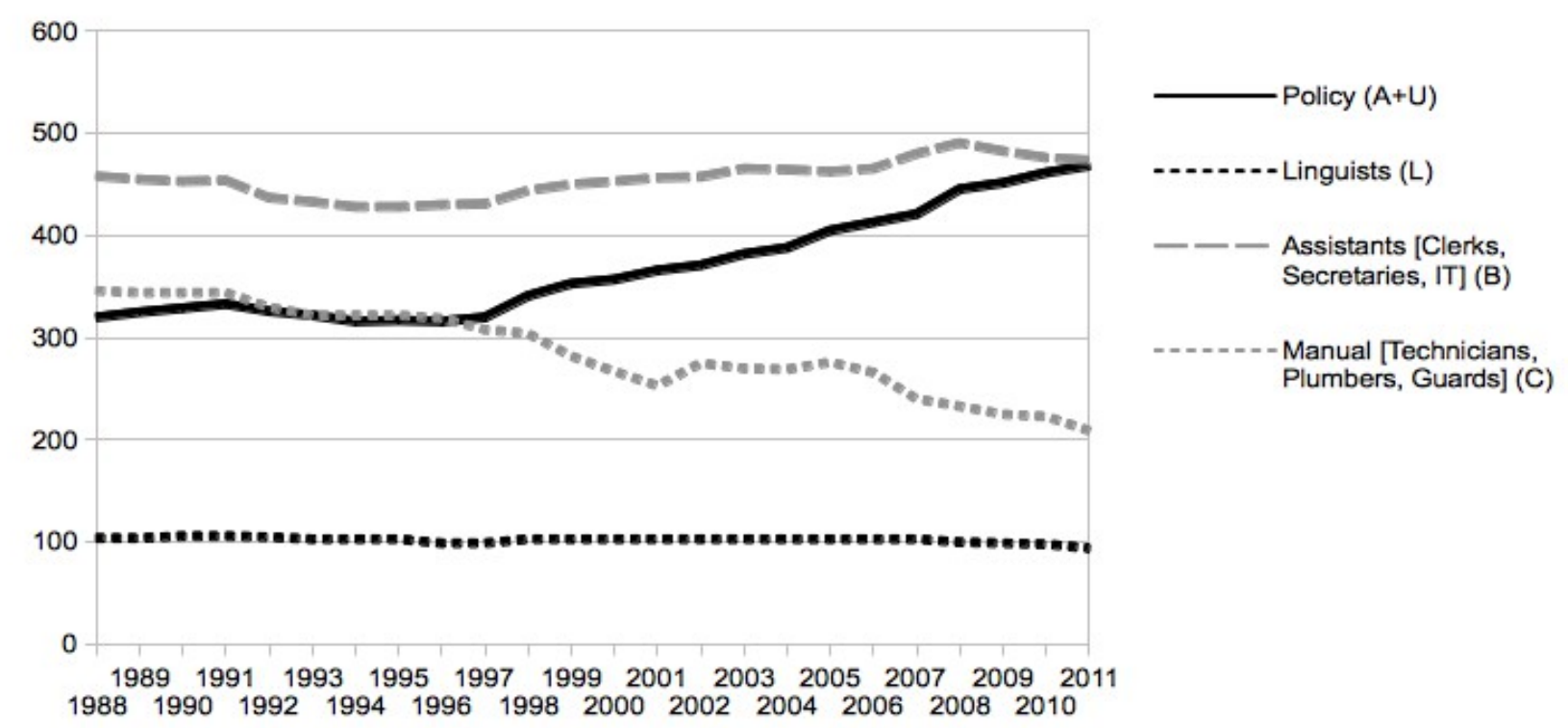

Figure 1: Resources of NATO International Staff; data provided by NATO officials.

In addition to this strong shift from technical to policy personnel, there are also developments in the allocation of resources between divisions. Executive Management, which brings together most of the support functions, for example, accounts for some $35 \%$ of officials. Under the current financial pressures, this overhead is being cut away (interview \#12). Budgetary cuts are also made in the Public Diplomacy Division, which will become less of a priority with the end of the Afghanistan mission in 2014. Similarly, the Operations Division will decrease in size. These are functional responses to the changes in the environment and therefore support hypothesis \#1.

There have furthermore been structural reforms. To increase staff, for instance, the Executive Secretariat was abolished in the early 2000s. Committee secretaries were integrated into the substantive divisions, thereby creating economies of scale (Kriendler 2005; interviewee \#9). There have been attempts to bring the International Staff and International Military Staff closer together by means of co-location. One interviewee furthermore notes that "we have consultants, temporaries, interns and voluntary national contributions" (\#9). Voluntary national contributions are 
interesting as they work at almost no cost to NATO. They stay for several months or years and there are normally around 30-50 at the same time (interview \#11).

Finally, staff consider that the workload has increased. One interviewee states that " $[w] e$ have 2-3 times as much work as when I first joined" (\#5). Another former official notes that he still has contact with some colleagues and that due to the heavy workload and uncertainty about the future, the "morale today is low". As one interviewee sums it up "[r]eforms are good when you eliminate redundancies ... [b]ut when you have fewer personnel, this does not work, because people simply have to do more jobs. Staff gets more overworked, and thus makes more mistakes ... [t]here is a mismatch and you cannot stretch endlessly" (\#8).

To conclude, budgetary policy has prevented overall increases in the International Staff and there is an ongoing effort to cut personnel. Generic rules, such as zero nominal or zero real growth, have been an important mechanism of control. It has prevented a sharp increase in staff following the various new tasks that NATO acquired post-1989. It has also made reform difficult amidst allies with competing preferences (hypothesis \#2). Yet gradual internal reforms have made the organization nonetheless considerably more efficient. Savings have not gone to the member states, but have been used to give the International Staff more tooth to deal with the new challenges of crisis management and collective security. There have been important changes behind the overall staff numbers. These changes show that full control of international secretariats and their institutional development by the member states is difficult. This is evidence for hypothesis \#3.

\section{Reforming the NATO Secretariat after the Cold War}

The second empirical part of the article analyzes the reform efforts more in detail. It traces the most important changes in the International Staff since 1989. It confirms that preference heterogeneity has been a major obstacle for reform (hypothesis \#2). When faced with uncertainty on institutional 
reform and the risk of losing control, allies prefer to stick with the status quo. They have been particularly reluctant to give up high-level posts in the organization (hypothesis \#2). Strong functional pressures have, nonetheless, led to changes (hypothesis \#1). Secretariat leadership, on the other hand, has not been a sufficient condition for change (hypothesis \#3). Secretaries-General have only made a significant impact in the area of employment policy.

Before going to the reforms of the 2000 s, it is useful to shortly discuss the development of the International Staff during the Cold War and the 1990s. The International Staff was created in 1951 to support the Secretary-General in servicing the North Atlantic Council and the various civilian committees. Although it was a sizable organization from the start, employing some 650 officials in 1956 (Jordan 1967: 170), the emphasis was on supportive functions. The Political Division only consisted, for example, of 15 people. During the Cold War, the International Staff developed. By 1988, it consisted of five substantive divisions (Political Affairs; Defence Planning; Defence Support; Infrastructure; Science) and employed 1228 officials (NATO 1989; Mouritzen 1990).

The significance of the end of the Cold War was not lost on the member states. Already on 5-6 July 1990, they issued the London Declaration “on a Transformed North Atlantic Alliance”, in which they noted a function for NATO in the collective security of the European continent (NATO 1990). It resulted in a plethora of partnerships and dialogues with Central and Eastern European countries, Russia and the former Soviet Republics. ${ }^{8}$ In addition, NATO was delegated a function in arms control and nuclear non-proliferation. This had a modest impact on the International Staff. It led to several changes within the Division of Political Affairs.

At the time of the fall of the Berlin War, the Division of Political Affairs had 49 staff members of whom 25 worked on Information and Press (Mouritzen 1990). The remaining 24 were split between the Political Affairs and Economics Directorate. Due to post-Cold War developments,

8 For example, the North Atlantic Cooperation Council (NACC), Partnership for Peace (PfP) and the Mediterranean Dialogue. 
the Political Affairs Directorate was expanded. It became home to five sections (Multilateral and Regional Affairs; Policy Planning; Partnership and Cooperation; Disarmament, Arms Control and Cooperative Security; Verification and Implementation Coordination). ${ }^{9}$ Political Affairs thus gained liaison officers and staff servicing the new committees (NATO Handbook 1999; interview \#1). It was a functional reform following the new tasks of NATO (support for hypothesis \#1).

At least as important became NATO's new role in crisis management. Following the war in former Yugoslavia (1991-1995), the United Nations (UN) Security Council authorized NATO to carry out military missions to monitor and enforce sanctions and the no-fly zone. At a later stage, NATO was also tasked to provide the UN operation with air support. Finally, NATO received a mandate to engage in combat operations leading to the Dayton agreement of 1995, which in turn led to its ground operation Implementation Force (IFOR). These crisis management operations were new territory for NATO yet became soon part of, what some consider, its core business.

These crisis management missions had, in particular, an impact on the NATO command structure, which almost immediately became subject of institutional reform (e.g. Barry 1996; Neumann 1998; Mayer 2014). It resulted, however, also in developments within the International Staff (support for hypothesis \#1). Notably, the member states established a Crisis Management and Operations Directorate within the Division of Defence Planning and Policy. The new directorate included sections on crisis management, council operations and peacekeeping (NATO 1999). By the end of the 1990s, the International Staff had thus made some staff available for crisis management and collective defence. In terms of overall structure, however, it still had the same five divisions as at the end of the Cold War.

9 The NATO International Staff has several divisions. Each division has a number of directorates. Directorates may in turn consist of various sections. 


\section{Robertson reforms}

Secretary-General Robertson entered office in 1999 after a critically important year for NATO. In the spring, the alliance had launched an air campaign against Serbia over Kosovo without a UN Security Council mandate. It had also deployed 60.000 peacekeepers as part of its Kosovo Force (KFOR). Moreover, NATO had seen its first post-Cold War enlargement round with the Czech Republic, Hungary and Poland joining the alliance. Robertson's predecessor had taken little interest in institutional reform and had "left the place in a mess" (interview \#3). Now that NATO had made a definite step towards crisis management and expanded its membership, the modest previous changes were no longer sufficient. Robertson's means were the NATO+ reforms, which he qualified as the "most radical internal change agenda in NATO's history" (quoted in Kriendler 2005: 14).

Interviewees describe the Robertson reform, which aimed at making internal processes more efficient, as inclusive. As one interviewee stated " $[t]$ he objective was to see how we can improve things. It was an stimulating attempt to involve all staff” (\#4). John Kriendler, a former high-level official, similarly writes (2005) that there were various working groups dealing with different aspects of reform. This was perhaps also part of the problem. One interviewee noted that the mode was "[1]et's try everything ... [t]hey should have limited themselves. None of the projects hit their targets" (\#5). After one-and-a-half year, the outside consultants hired for reform were sent home and very little reached the North Atlantic Council (interview \#4). It was an instance of an overcrowded agenda and a lack of leadership (support for hypothesis \#3).

The Robertson reforms were more significant in terms of structural changes. Following the intervention in Kosovo and with a view to the operation in Afghanistan, the Crisis Management and Operations Directorate became a division in its own right (Operations Division). This was a clear reflection of the priority area that crisis management operations had become for NATO. It was, once again, the logical thing to do from a functionalist perspective (hypothesis \#1). It was also an 
instance in which the overriding interest of NATO trumped the parochial opposition of some of the member states, including some of the newer member states that continued to champion NATO's role in collective defence.

The establishment of the Operations Division set in motion some further structural changes. Since the Division of Defence Planning and Operations lost much of its staff, some offices were shuffled between what became the Division of Political Affairs and Security Policy (PASP) and the Division of Defence Policy and Plans (DPP). Many of these changes were "cosmetic" (interview \#3 and \#6). Another reform was the creation of the Public Diplomacy Division (PDD), which merged the Office for Information and Press with the Science Division. While few people understood the logic, it gave press a higher profile in the organization. This was a reaction to Kosovo, which had resulted in a lot of exposure (interview $\# 5$ and $\# 12$ ). A side effect of the structural reorganization was the establishment of a new Assistant-Secretary-General (ASG) position, This allowed a highlevel appointment for France (Kriendler 2005). Finally, support functions were merged into a behemoth called Executive Management.

The most important stamp that Robertson left on the International Staff was, however, his contract policy. Prior to Robertson's tenure, employment contracts had a duration of three years and were typically renewed once or twice. Once an official had worked for ten years, he/she got an indefinite contract. Robertson wanted to create a more permanent staff corps and to open up the possibilities for internal promotion. He therefore gave all personnel with a limited duration contract at once a permanent contract. From the principal-agent literature, this move was quite extraordinary. As noted above, contract policy is one way for the member states to control the secretariat. Permanent officials have more autonomy than temporary staff, as they build up expertise and are more difficult to get rid of. That Robertson and successive Secretaries-General have had quite some authority over the contracts of their own staff is thus remarkable (interview \#12).

The appreciation in the International Staff of this reform was mixed (see also Mouritzen 
2013: 6). As one official notes "Robertson woke up one morning and slipped back into good old Labour policy ... [w]e thought you are crazy, but we were not crazy enough not to take advantage" (\#5). Two (former) Private Office interviewees completely agree. One states that such contract policy "is a bummer, because people come in at 25/26 and then get a permanent contract for life. This is not the kind of flexibility that we need and that we are used to in my country". The other agrees, indefinite contracts "made him very popular but it was not a smart move for the organization".

Others, on the other hand, identify with the need to have an esprit de corps and possibilities for internal career enhancement (interview \#4 and \#8). Many officials object to the fact that under Secretary-General Rasmussen, contract policy is going in the opposite direction. Since 2012, it is no longer possible for most policy staff to work in the International Staff for more than six years. As a result, one interviewee notes, “[w]e will no longer build up experience like we used to" (\#5). Another states that "[a] lot of experience and memory gets lost. NATO is also no longer a career" (\#8). Finally, one interviewee nuances the discussion: "there is some disquiet in the organization ... but we will get to a good balance eventually" (\#2).

When taking a broader look at the institutional changes under Secretary-General Robertson, two issues are worth pointing out. First, through the creation of an Operations Division and a Public Diplomacy Division, the NATO International Staff was reformed to better deal with environmental demands on the organization. The creation of these two divisions was a to clear functional reaction following the interventions in Kosovo and Afghanistan (hypothesis \#1). Second, Robertson has had a surprising amount of discretion in changing personnel policy. Most of these contract changes have been beyond the control of the member states (hypothesis \#3). Contract policy was considered an internal issue for the International Staff. 


\section{Vahr reforms}

The Robertson reforms had hardly sunk in, when a new round of reform was initiated. The initiative came from the United States and its Secretary of Defence, Donald Rumsfeld, who wanted to cut the overhead (interview \#7). The new Secretary-General Jaap de Hoop Scheffer was not uninterested in reform, but he wanted to keep the initiative in his own hands (ibid.). He asked the member states to put forward a candidate to lead these reform efforts. This became Jesper Vahr, the current Director of the Private Office. Vahr had been the Danish Deputy Permanent Representative and was at the time the Director of Security Policy in Copenhagen. He was supported by four internal officials and they presented their proposal after one year (ibid.; interview \#9).

It is important to point out that the Vahr reforms were not only about the International Staff. They also dealt with the working methods of the North Atlantic Council, the committees, and the interaction between the civilian and military elements of NATO governance (see Kriendler 2006 for details). Regarding the International Staff, Vahr wanted to have only " $[\mathrm{t}]$ hree 'super' policy divisions [i.e. operations, capabilities and partners] supported by enabling divisions" (ibid.: 2). Each of these divisions would address one of the core tasks of NATO. In other words, the approach was functional and included a major element of re-design. Vahr looked at NATO's core tasks and organized the International Staff accordingly. His report is can therefore be considered a functional benchmark against which actual reform can be measured.

While few interviewees dispute that Vahr wrote a good report (interview \#6), the member states did little with it. One interviewee states bluntly: "He completely failed. Some nations did not consider his proposals bold enough, not practical enough, not interesting enough" (cf. Kriendler 2006). A problem was perhaps the approach. As an interviewee noted, "[t]he Vahr reforms were presented as a package and it was indigestible for the nations. Elements have been cherry-picked" (\#9). Similarly, someone stated "[h]e sold it in a confrontal manner. My way or the highway" (\#6). 
An interviewee argued that "he was not in a position of authority vis-à-vis the nations, and the staff and everyone" (\#3). Importantly, once the United States realized that it would lose high-level posts in the International Staff as a result of the reforms, it withdrew its support (interview \#7).

In other words, preference heterogeneity and the risk of the loss of control made the member states wary of the proposals (hypothesis \#2). The bargaining style and the lack of leadership did not help either (hypothesis \#3). Finally, contrary to the previous and 2012 reform efforts, there was less of a functional need to change the organization (hypothesis \#1). It is therefore not surprising that not much was implemented. In fact, few interviewees spontaneously talked about the Vahr reforms. One interesting change is perhaps the physical co-location of officials from the International Staff and International Military Staff. As the debates over co-location display some of the political struggles over institutional design, it is worth to elaborate a bit.

NATO has always had parallel civilian and military structures. In the Brussels headquarters, the International Staff supports the Secretary-General, the North Atlantic Council and the civilian committees. The International Military Staff provides the Military Committee with expertise. There is thus 'stove-piping' within NATO. In spite of the fact that individual officials are working on similar horizontal, thematic and area issues, the International Staff and International Military Staff traditionally hardly interact. Merging the relevant staffs could, from a functional perspective, lead to economies of scale (Kriendler 2005, 2006).

Various member states have, however, always resisted integration. They have argued that the advice of the International Military Staff should not be 'contaminated' with all sorts of political and diplomatic considerations. This goes back to a Weberian and Huntington type of vision on politicalbureaucratic and civil-military relations. What makes this discussion complex is the politicized separation between civilians and the military in several member states. This has made full integration of the International Staff and International Military Staff a bridge too far. It is too politically sensitive for countries such as Germany and Turkey (support for hypothesis \#2). Some of 
the smaller member states fear that their position in the Military Committee gets undermined by SHAPE expertise (Mouritzen 2013: 9). The compromise following the Vahr report was to physically co-located offices without changing the reporting hierarchies.

The experience so far is mixed. One interviewee notes that "[i]t has proofed successful" (\#9). Others question whether the impact was significant. An interviewee states that " $[t]$ his has been a cosmetic change ... [t]he 100 meters between the offices was never the obstacle. People were already able to find each other" (\#6). Similarly, one states "I do not see a difference. There is no difference, very little difference. Physical co-location is not the same as decision-making structure" (\#2). Importantly is that the whole operation of moving offices has been costly. Furthermore, it is relevant to mention that when NATO moves into its new headquarters (currently foreseen in 2016), offices will continue to be co-located.

Finally, it is worth noting that under Secretary-General De Hoop Scheffer, the employment policy concerning getting an indefinite contact became more stringent. This was to counter negative effects from the Robertson reforms. In addition, De Hoop Scheffer has made a conscience effort to introduce rotation for senior posts. Several Deputy Assistant-Secretary-General posts, for example, were opened up for open competition leading to career advancement of internal candidates. He also insisted to choose his own Deputy Directors in the Private Office (from a shortlist provided by the relevant member state). ${ }^{10}$ These changes resulted in more autonomy and are an instance of secretariat leadership (hypothesis \#3).

\section{Rasmussen reforms}

The appointment of Secretary-General Anders Fogh Rasmussen in 2009 resulted, once again, in momentum for reform. It started with the nomination itself. Turkey made clear that it was opposed 
to the Rasmussen candidature due to his stance as Danish Prime Minister during the Mohammed cartoon controversy in 2005-2006. Rasmussen therefore provided Turkey with various reassurances. He made a public statement and he promised senior positions (Waterfield, 2009; US Embassy Copenhagen 2009). He also appointed Vahr, who was at the time the Danish ambassador in Ankara (US Embassy Copenhagen 2009) and the most experienced Dane when it came to NATO issues, as his Director of the Private Office.

Giving senior positions to Turkey was never going to be easy, as it meant taking away posts from the other member states. The situation was, however, facilitated through the creation of a new division for Emerging Security Challenges (ESC). The division, a merger of various sections across the International Staff, would give forward-looking policy a stronger foothold in the organization in line with the new Strategic Concept. Turkey, however, did not like what it saw and rejected the post of Assistant-Secretary-General (interview \#5). It received instead, in 2010, the position of AssistantSecretary-General for Defence Policy and Planning.

Much more fundamental reform was, however, suggested in 2011 in light of the economic crisis and the operation in Afghanistan resulting in the International Staff Review process. While some momentum came from the United States, Germany and like-minded allies (interview \#5 and \#12), the real leadership seems to have come from Secretary-General, Vahr and the Private Office. ${ }^{11}$ Three options for the structural reform of the International Staff were discussed. The first option essentially built on the Vahr proposal of three super divisions plus Executive Management. These divisions would each deal with one of NATO's core tasks. In addition, there would be supporting offices with a low status. The second option consisted of supporting offices at a higher level. The third option was close to the status quo.

In many ways, this reform effort would theoretically stand a better chance than the previous Vahr proposal. The ongoing economic crisis - and the corresponding budgetary pressures - has

11 Already before Rasmussen entered office he stated that headquarters reform and flexibility in staffing were among his priorities (US Embassy Copenhagen 2009). 
made International Staff reform an even greater necessity. The approach to reform under Rasmussen had a much stronger problem-solving dynamic (hypothesis \#3). In addition, this latest reform effort benefited from the personal leadership of the Secretary-General . Despite all these odds in favor of the Rasmussen reforms, the member states still decided to not to adopt the package. The priorities of the member states in international security remain heterogeneous and, as a result, the member states could not agree on how to distribute key posts in this new structure (hypothesis \#2).

It is useful to shortly discuss these senior posts further, as they are an important way for the member states of exerting influence (Kleine 2013). Traditionally, member states have monopolized strategic posts in NATO. Germany, for example, has long occupied Political Affairs as this division deals with Russia. Defence Investment has been for the United States. The United Kingdom has had the Assistant-Secretary-General for Operations. The Wikileaks telegrams are, in this respect, illuminating. While the US "has always been among the strongest proponents of NATO reform" (US Mission 2009; cf. US Embassy Copenhagen 2009), the State Department makes clear that "[a]llies who pay a large share of the budget and who present well-qualified candidates should retain some rights to a minimum quota of positions. If not legacy positions, perhaps ... legacy numbers" (US State Department 2009). And when it comes to security, intelligence and defence investment, the US wants to keep control (ibid.).

This 'flags-to-posts' system has become a major impediment to International Staff reform. The accession of many new countries and the return of France to the military command has meant that many more member states now qualify for top-level positions. De Hoop Scheffer already set in motion a process to end legacy positions and Rasmussen has been effective in opening up all jobs, including those of Assistant-Secretary-General, to open competition. ${ }^{12}$ The trouble is, however, with the reduction of senior positions. Creating new posts (e.g. Assistant-Secretaries-General for Public Diplomacy and Emerging Challenges) was easy, but if the International Staff is downsized to three

12 The open competition for Assistant-Secretaries-General in 2013 has meant the end of a number of legacy positions. Germany, for example, 'lost' Political Affairs to Greece. Germany was nonetheless 'compensated' with the post of Defence Planning and Policy. The major allies thus remain represented at the highest bureaucratic level. 
divisions, it becomes difficult for the member states to get senior posts. This makes control uncertain (hypothesis \#2) and might result in unwanted effects.

The Rasmussen reforms were, in some respects, a test-case for change at NATO. Austerity created a rationale for reform and the Rasmussen team had the experience needed. That significant structural reform was not achieved signifies the importance that member states attach to the control of NATO. It was unclear how institutional change would affect the senior managerial level and thereby the access that member states have to the highest level of policy-making (hypothesis \#2). While reducing the International Staff to three divisions was not achieved, Rasmussen was more successful in incremental reforms relating to personnel policy. He changed employment contracts from permanent to temporary. In addition, he achieved some results in opening up high-level jobs to open competition (hypothesis \#3).

\section{CONCLUSION}

Many international organizations face pressures to adjust their institutions to changing international environments. Oftentimes, they are held hostage by disagreements among the member states. The case of NATO is an obvious example. Since the end of the Cold War, NATO has started various partnerships and has launched many military operations. How has this change in functions informed institutional design in light of multiple principals and diverging preferences?

This article has shown that institutional form does not automatically follow function. ${ }^{13}$ The preference heterogeneity of the member states has, as expected, been a major obstacle for change (support for hypothesis \#2). First, several member states have continuously insisted on zero budgetary growth. This has prevented NATO from recruiting personnel. New activities thus had to come at the expense of existing ones, while the newer member states continued to insist on NATO's

13 The data in this article comes mostly from interviews, as most NATO documents are classified. While efforts have been made to ensure the accuracy of the data (see also acknowledgements), interview data has its drawbacks. These need to be taken into account with a view to the conclusions. 
role in collective defence. Second, the member states, including the United States, have been very reluctant to give up the high-level posts for the risk of losing control. Third, the member states, including Germany and Turkey, have not been able to agree on a merger of the International Staff and the Military Staff. The member states care about the NATO International Staff and want to keep control (Mouritzen 2013).

Yet modest institutional reform has still taken place. The establishment of the Operations Division was perhaps the clearest reaction to functional demands (hypothesis \#1). But so have been developments in the offices dealing with partnerships and press. The key question, of course, for further research, is under which conditions functional demands trump diverging preferences. There have also been several incremental developments in the International Staff, which have gone mostly unnoticed. Beyond the control of the member states, policy tasks have been prioritized at the expense of support functions. Policy staff has gone up by $46 \%$ in a decade. The Secretaries-General have been influential in changing the details of contract policy and opening up senior positions to open competition. This is evidence for hypothesis \#3. When it comes to structural changes in the organization, however, secretariat leadership has not proved a sufficient condition for reform. The member states have defied the political entrepreneurship of Rasmussen and Vahr. Member states preferences and the uncertainty about outcomes remained too large obstacles to overcome.

This article has been about discussing institutional change in the specific case of the NATO secretariat, but the findings have relevance for international organizations more generally. Many international organizations are subject to environmental change and have to adjust their machinery to keep up. It is important to recognize, in this respect, that the dominant role of member states as veto players needs to be nuanced. The member states are not fully immune to systemic pressures nor incremental developments, both of which can have a tangible effect. Importantly, however, in the case of NATO, they have resisted structural reforms that touched upon their control of the International Staff. Changes to top-level bureaucratic positions are one obvious example. This is 
clearly something that has relevance to many international organizations (Kleine 2013).

\section{ACKNOWLEDGEMENTS}

This article is based on 12 interviews with (former) officials from the NATO International Staff in 2012. Almost all interviews were at the level of Private Office, Deputy Assistant-Secretary-General or Section Head and the response rate was approximately $80 \%$. Interviews were not recorded in line with NATO policy. Many interviewees have read draft versions of the paper and have provided factual comments. The author finally likes to thank Joe Burton, Thomas Gehring, Sebastian Knecht, John Kriendler, Duncan Snidal, Mark Webber, and four anonymous reviewers for their detailed comments. The usual disclaimer applies.

The research leading to these results has received funding from the People Programme (Marie Curie Actions) of the European Union's Seventh Framework Programme (FP7/2007-2013) under REA grant agreement $n^{\circ}[298081]$.

\section{REFERENCES}

Abbott, K. and D. Snidal (1998) 'Why States Act through Formal International Organizations', Journal of Conflict Resolution 42(1): 3-32.

Asmus, R. (2004) Opening NATO's Door: How the Alliance Remade itselffor a new Era, New York: Columbia University Press. 
Barry, C. (1996) 'NATO's combined joint task forces in theory and practice', Survival 38(1): 81-97.

Beach, D. (2005) The Dynamics of European Integration: Why and when EU institutions matter, Basingstoke: Palgrave Macmillan.

Biermann, F. and B. Siebenhüner (eds) (2009) Managers of Global Change: The Influence of International Environmental Bureaucracies, Cambridge: M.I.T. University Press.

Dijkstra, H. (2012) 'Efficiency versus Sovereignty: Delegation to the UN Secretariat in Peacekeeping', International Peacekeeping 19(5): 581-596.

Dijkstra, H. (2013) Policy-Making in EU Security and Defense: An Institutional Perspective, Basingstoke: Palgrave Macmillan.

Downs, A. (1967) Inside Bureaucracy, Boston: Little, Brown and Company.

Falkner, G. (ed.) (2011) The EU's Decision Traps: Comparing Policies, Oxford: Oxford University Press.

Finke, D., T. König, S.O. Proksch and G. Tsebelis (2012) Reforming the European Union: Realizing the Impossible, Princeton: Princeton University Press.

Hawkins, D. et al. (eds) (2006) Delegation and Agency in International Organizations, Cambridge: Cambridge University Press. 
Herd, G. and J. Kriendler (eds) (2013) Understanding NATO in the 21st Century Alliance

Strategies, Security and Global Governance, London: Routledge.

Jordan, R. (1967) The Nato international staff/secretariat, 1952-1957: a study in international administration, Oxford: Oxford University Press.

Jupille, J., W. Mattli and D. Snidal (2013) Institutional Choice and Global Commerce, Cambridge: Cambridge University Press.

Kaplan, L. (2004) NATO Divided, NATO United: The Evolution of an Alliance, Westport: Praeger Publishers.

Keohane, R. (1984) After Hegemony: Cooperation and Discord in the World Political Economy, Princeton: Princeton University Press.

Kleine, M. (2013) 'Trading control: national fiefdoms in international organizations', International Theory 5(3): 321-346.

Koremenos, B., C. Lipson and D. Snidal (2001) 'The rational design of international institutions', International Organization 55(4): 761-799.

Kriendler, J. (2005) 'NATO Headquarters Transformation: Getting Ahead of the Power Curve' Special Series 05/29, Conflict Studies Research Centre, UK Defence Academy.

Kriendler, J. (2006) 'Transforming NATO HQ: The Latest Hurrah', Special Series 06/30, Conflict 
Studies Research Centre, UK Defence Academy.

Lake, D. and M. McCubbins (2006) 'The logic of delegation to international organizations', in D. Hawkins et al. (eds), Delegation and Agency in International Organizations, Cambridge: Cambridge University Press.

Lugar, R. (1993) 'NATO: Out of Area or Out of Business', Intervention during debate at US State Department, 2 August 1993.

Mayer, S. (ed.) (2014) NATO's Post-Cold War Politics: The Changing Provision of Security, Basingstoke: Palgrave Macmillan.

Menon, A. and J. Welsh (2011) 'Understanding NATO's Sustainability: The Limits of Institutionalist Theory', Global Governance 17(1): 81-94.

Merton, R. (1940) 'Bureaucratic Structure and Personality', Social Forces 18(4): 560-568.

Mouritzen, H. (1990) The international civil service: a study of bureaucracy: international organizations, Darmouth: Aldershot.

Mouritzen, H. (2013) 'In spite of reform: NATO HQ still in the grips of nations', Defense and Security Analysis, DOI: 10.1080/14751798.2013.843833

Oestreich, J. (ed.) (2012) International Organizations as Self-Directed Actors: A framework for analysis, London: Routledge. 
NATO (1989) NATO Handbook, Brussels: NATO Information Service.

NATO (1990) Declaration on a Transformed North Atlantic Alliance, London, 5-6 July.

NATO (1999) The NATO Handbook, Brussels: NATO Office of Information and Press.

NATO (2010) Active Engagement, Modern Defence: Strategic Concept for the Defence and Security of the Members of the North Atlantic Treaty Organization [New Strategic Concept], Brussels: NATO Public Diplomacy Division.

Nielson, D. and M. Tierney (2003) 'Delegation to International Organizations: Agency Theory and World Bank Environmental Reform', International Organization 57(2): 241-276.

Neumann, K. (1998) 'NATO's new military command structure', NATO Review 46(1): 10-14.

Pierson, P. (2000) 'The Limits of Design: Explaining Institutional Origins and Change', Governance 13(4): 475-499.

Pierson, P. (2004) Politics in Time: History, Institutions and Social Analysis, Princeton: Princeton University Press.

Rynning, S. (2005) NATO Renewed: The Power and Purpose of Transatlantic Cooperation, New York: Palgrave. 
Rynning, S. (2012) NATO in Afghanistan: The Liberal Disconnect, Stanford: Stanford University Press.

Scharpf, F. (1988) The Joint-Decision Trap: Lessons from German Federalism and European Integration, Public Administration 66(3): 239-278.

SIPRI (1990-2012) Yearbook, Oxford: Oxford University Press.

Stone, R. (2011) Controlling Institutions: International Organizations and the Global Economy, Cambridge: Cambridge University Press.

Streeck, W. and K. Thelen (2005) 'Introduction: Institutional Change in Advanced Political Economies', in W. Streeck and K. Thelen (eds) Beyond Continuity: Institutional Change in Advanced Political Economies, Oxford: Oxford University Press.

Tallberg, J. (2002) 'Delegation to Supranational Institutions: Why, How, and with What Consequences?', West European Politics 25(1): 23-46.

Tallberg, J. (2006) Leadership and Negotiation in the European Union, Cambridge: Cambridge University Press.

Thatcher, M. and A. Stone Sweet (2002) 'Theory and practice of delegation to non-majoritarian institutions', West European Politics 25(1): 1-22.

Trondal, J. (2006) 'Governing at the frontier of the European Commission: The case of seconded 
national officials', West European Politics 29(1): 147-160.

Trondal, J., C. van den Berg and S. Suvarierol (2008) 'The Compound Machinery of Government: The Case of Seconded Officials in the European Commission', Governance 21(2): 253-274.

Tsebelis, G. (2002) Veto Players: How Political Institutions Work, Princeton: Princeton University Press.

US Embassy Copenhagen (2009) 'Nato Syg-designate Eager To Begin Needed Reforms', 4 May, 09COPENHAGEN206, online available at Wikileaks.org (accessed 20 November 2012).

US Mission (2009) 'Nato I.s. Reform Guidance Needed By June 11', 9 June, 09USNATO000249, online available at Wikileaks.org (accessed 20 November 2012).

US State Department (2009) 'Usnato Guidance: Nato Reform, Senior I.s. Positions', 10 June, 09STATE059968, online available at Wikileaks.org (accessed 20 November 2012).

Waterfield, Bruno (2009) 'Rasmussen “to give Turkey senior posts in Nato", The Telegraph, 6 April.

Wallander, C. and R. Keohane (1999) 'Risk, Threat, and Security Institutions', in: H. Haftendorn, R. Keohane and C. Wallander (eds) Imperfect Unions: Security Institutions over Time and Space, Oxford: Oxford University Press.

Webber, M., J. Sperling and M. Smith (2012) NATO's Post-Cold War Trajectory Decline or 
Regeneration, Basingstoke: Palgrave.

Yost, D. (1998) NATO transformed: The Alliance's new roles in international security, Washington: United States Institute of Peace. 